\title{
A review of natural remedies commonly used by Ethiopian immigrants in the USA
}

\author{
Bisrat Hailemeskel PharmD ${ }^{1}$, Fekadu Fullas $\mathrm{PhD}^{2 *}$, Anteneh Habte $\mathrm{MD}^{3}$, Ranyia Ali Al-Matari PhD ${ }^{1}$, David Brewer ${ }^{1,4}$
}

Hailemeskel B, Fullas F, Habte A, et al. A review of natural remedies commonly used by Ethiopian immigrants in the USA. Curr Res Integr Med 2017;2 (3): 31-36

\section{ABSTRACT}

This review discusses the most commonly used natural remedies by Ethiopian immigrants in the United States of America (USA). The data is extracted from a previous survey by the same authors who established that more than half of the respondents $(57.5 \%)$ used supplements and herbs for a wide array of ailments in the preceding 5 years. Ginger, garlic and flaxseed were the most commonly used herbs by the survey participants.

Key Words: Natural remedies; Ethiopian immigrants; Culture; Tradition
$\mathrm{N}$ tural herbs and supplements have been used for medicinal purposes since time immemorial. Countries like Ethiopia and other non-western civilizations have utilized these treatment modalities extensively. A 2004 World Health Organization (WHO) review established that Ethiopia led all nations with $90 \%$ of its population using traditional medicine for primary health care (1).

There appears to be resurgence in the utilization of complementary and alternative medicine (CAM) with a steady increase in the past several decades. Immigrant communities tend to bring their cultures and traditions with them, and the Ethiopian population in the USA resorts to natural remedies at a comparable rate with the use of this modality in Ethiopia itself. This may be in part due to lack of access to conventional healthcare, inability to afford pharmaceuticals, or personal preferences among other factors.

\section{METHODS}

A recent survey looked into the utilization of natural remedies among Ethiopian immigrants in the USA (2). A total of 695 eligible people were invited to participate with a $51.5 \%$ response rate. 206 (57.5\%) [95\% CI, $52.5 \%$ to $62.8 \%$ ] of the respondents used herbs and supplements in the past five years. The most commonly used herb was ginger $(170,82.5 \%)$, followed by garlic $(163,79.1 \%)$ and flaxseed $(124,60.2 \%) .139(67.2 \%)$ of the respondents reported using both ginger and garlic. About $55 \%$ of our survey respondents who reported CAM use did not share this information with their health care providers. The current review is based on the results obtained from this survey. It attempts to take a more in-depth look at the most commonly used natural remedies by the survey participants, and stratifies the findings by age, gender, level of education and length of stay in the Unites States (Table 1). The study was approved by the Institutional Review Board of Howard Unversity.

\section{Zingiber officinale}

Common name: Ginger; Vernacular name: Zinjbil

Ginger was the most commonly used herb among respondents of our survey $(170,82.5 \%)$. The majority of ginger users $(91,53.5 \%)$ have lived in the USA for over 15 years and there was a slight preponderance of males (88, $51.8 \%)$. The age group most frequently represented was between 31 and 40 $(43,25.3 \%)$ and $75(44.1 \%)$ reported a yearly income of less than $\$ 50,000$. 62 (36.3) had a master's degree education or higher (Table 1).

Ginger grows perennially and belongs to the family Zingiberaceae. The plant is indigenous to southeastern Asia, and is cultivated in the USA, China, West Indies and tropical regions (3). The cultivation of ginger was started in Ethiopia during the $13^{\text {th }}$ century after the Arabs transported it from India to East Africa (4). The tuberous rhizomes are widely used as spices in many western and Asian-American foods. They are also found in a multitude of over the counter (OTC) remedies and supplements.

Ginger is used for a wide array of ailments. It is orally ingested to treat anorexia, motion sickness, colic, dyspepsia, diarrhea, post-surgical nausea and vomiting, and other digestive conditions. It can also be used to treat rheumatoid arthritis, upper respiratory problems and as a diuretic. It is applied topically to treat skin burns (5).

Ginger can be used orally without concern for toxicity or major adverse events. Heartburn, diarrhea, and mouth irritation have been reported (6). The preponderance of evidence suggests that use of ginger in the amount found in foods during pregnancy is likely safe, while the same cannot be said about use while breastfeeding as there is not enough information (5).

\section{Allium sativum}

Common name: Garlic; Vernacular name: Netch shinkurt

Garlic was ranked a close second in frequency of use among our survey respondents $(163,79.1 \%)(2)$. This may stem from the fact that it is a commonly used ingredient in Ethiopian cuisine. Garlic was used by both genders in almost equal proportion and the demographics and social characteristics of users closely resembled that of ginger consumers (Table 1).

Garlic is closely related to onions and belongs to the family Amaryllidaceae/ Liliaceaea $(7,8)$. It is believed that garlic originated from Central Asia, introduced to the Mediterranean region, and now it is cultivated worldwide (9). When ingested, garlic can be used to treat a host of conditions including hypertension, coronary artery disease, earaches, diabetes, and menstrual disorders (8). It is also used in the prevention of several forms of cancer including breast cancer, lung cancer, colorectal cancer, and prostate cancer (7). Garlic can be used topically to treat oral candidiasis, and skin conditions such as tinea corporis, tinea cruris, tinea pedis and onychmycosis (8).

According to a survey administered to 125 traditional healers on the medicinal uses of garlic among rural and semi-urban residents of the Southern Nations Nationalities and Peoples Regional State (SNNPR) in Ethiopia, the rates of garlic use reported by these healers were: for the treatment of common cold (88\%), malaria (85\%), cough and lung TB (66\%), hypertension (57\%), wounds (25\%), sexually transmitted diseases (22\%), mental illnesses (22\%), kidney disease (19\%), and liver diseases (16\%). In this same study, the healers believed that the medicinal content lies in the broad-bulb which must be taken raw (10).

There is no clinical evidence that suggests that the use of a garlic extract is unsafe in the treatment of children, pregnant women, or women that are breastfeeding. However, ingestion of garlic can lead to body odor, burning of the mouth, esophagus and stomach, digestive tract problems, light-

${ }^{1}$ College of Pharmacy, Howard University, Washington, USA; ${ }^{2}$ UnityPoint Health-St. Luke's, Pharmacy Department, Iowa, USA; ${ }^{3}$ West Virginia University School of Medicine, Morgantown, USA; ${ }^{4}$ PharmD Student, College of Pharmacy, Howard University, Washington, USA

Correspondence: Dr. Fekadu Fullas, UnityPoint Health-St. Luke's, Pharmacy Department, 2720 Stone Park, Boulevard, Sioux City, Iowa, 51104. USA. Telephone: 712-2666156, e-mail Fekadu.Fullas@unitypoint.org orFeFuBal@aol.com

Received: October 28, 2017, Accepted: November 08, 2017, Published: December 04, 2017 
headedness, and insomnia. Toxic dermatitis has been reported with topical application. Repeated exposure to garlic dust can cause asthmatic reactions. Increased risk of bleeding has been reported with oral garlic (11).

\section{Linum usitatissimum}

Common name: Flaxseed; Vernacular name: Telba

Flaxseed was the third most commonly reported herbal product by our survey respondents $(124,60 \%)$. The demographics of flaxseed users closely mirrored that of ginger and garlic users with a slight preponderance $(56.5 \%)$ of females (Table 1).

Flaxseed is a fibrous crop which originated from India and was domesticated in the Middle East. It is now produced in Canada, USA, Europe and Africa (12). It belongs to the family Linaceae, and is rich in the omega-3 fatty acid alpha-linolenic acid (13). Canada is the leading flaxseed producer, followed by China, United States, India and Ethiopia (12). Ethiopia is the fifth largest producer of flaxseed oil worldwide, and it is the country's major oil export second only to Niger seed oil (Guizotia abyssinica) $(13,14)$.

In Ethiopia, flaxseed is used as food; the seeds are usually roasted, ground added to grain/legume stew (shiro wot). It is also consumed in the form of porridge. Limited amounts are also pressed locally for its edible oil (15). In folk medicine, flaxseed is taken orally to treat diarrhea, constipation, IBS, enteritis, ulcerative colitis, and several other gastrointestinal disorders. It can also be used to treat the symptoms of diabetes, acne, high cholesterol, cardiovascular disease, and other heart conditions. Flaxseed is also believed to be useful for certain cancers and mental disorders (13).

There are no restrictions regarding the use of flaxseed in pregnancy or lactation. However, because of its laxative effect and the release of cyanide, the use of fresh plant is not recommended in pregnant and breast-feeding women (16).

\section{TABLE 1A}

Demographic characteristics of participants using herbs $(A)$
Ground flaxseed is found in the local markets in Ethiopia as packaged food and fitness/health-food supplement because of its health properties.

Honey

Vernacular name: Ma'ar

Approximately half of our survey respondents (100, 48.5\%) reported consuming honey over the preceding five years. $53 \%$ (53) were female with two-thirds $(66,66 \%)$ reporting a yearly income of up to $\$ 100,000$, and one half $(50,50 \%)$ having attained a Master's degree or higher. The most frequent age range, and years lived in the USA were $51-60(26,26.0 \%)$ and $>15$ years $(67,67.0 \%)$ respectively (Table 1$)$.

Honey, which at one time was regarded as liquid gold, has always been a sought-after commodity in the Horn of Africa. Little has changed today, and Ethiopia remains one of the world's largest honey producers, and by far Africa's largest producer. Some of the world's most refined but little-known honeys, such as the white honey of Tigray, come from Ethiopia. There are approximately 1.5 million beekeepers in Ethiopia and 8 to 10 million bee colony hives.

Currently, $80 \%$ of Ethiopian honey is used to brew honey wine (tej), with $5 \%$ rural household consumption, and $15 \%$ marketed as table honey (both domestic and export) $(17,18)$. Honeybees collect nectar to make honey, pollinating flowers in the process. They are found in all regions that have an abundance of flowers. Most honey products are considered safe, but some variations that are produced from the plants of the genus Rhododendron have proven to be toxic in humans. There is also concern that infants may contract botulism by consuming honey as it can be contaminated by spores of the bacteria (19).

\begin{tabular}{|c|c|c|c|c|c|c|c|}
\hline Variables & $\begin{array}{l}\text { Garlic (Allium } \\
\text { Sativum) } \mathrm{N}=163\end{array}$ & $\begin{array}{c}\text { Flaxseed (Linum } \\
\text { usitatissimum) } \\
\mathrm{N}=124\end{array}$ & $\begin{array}{l}\text { Lemon (Citrus } \\
\text { limon) } \mathrm{N}=87\end{array}$ & Honey $N=100$ & $\begin{array}{c}\text { Eucalyptus } \\
\text { (bahr zaf) } \mathrm{N}=70\end{array}$ & Vitamins $\mathrm{N}=75$ & $\begin{array}{c}\text { Boswellia/ } \\
\begin{array}{c}\text { Commiphora (itan)/ } \\
\text { (kerbe) } \mathrm{N}=36\end{array}\end{array}$ \\
\hline \multicolumn{8}{|l|}{ Age } \\
\hline $18-30$ & $12.9 \%(\mathrm{~N}=21)$ & $9.7 \%(\mathrm{~N}=12)$ & $12.6 \%(\mathrm{~N}=11)$ & $13.0 \%(\mathrm{~N}=13)$ & $8.6 \%(\mathrm{~N}=6)$ & $10.7 \%(\mathrm{~N}=8)$ & $16.7 \%(\mathrm{~N}=6)$ \\
\hline $31-40$ & $25.2 \%(\mathrm{~N}=41)$ & $24.2 \%(\mathrm{~N}=30)$ & $23.0 \%(\mathrm{~N}=20)$ & $24.0 \%(\mathrm{~N}=24)$ & $30.0 \%(\mathrm{~N}=21)$ & $20.0 \%(\mathrm{~N}=15)$ & $25.0 \%(\mathrm{~N}=9)$ \\
\hline $41-50$ & $25.8 \%(\mathrm{~N}=42)$ & $28.2 \%(\mathrm{~N}=35)$ & $26.4 \%(\mathrm{~N}=23)$ & $23.0 \%(\mathrm{~N}=23)$ & $28.6 \%(N=20)$ & $18.7 \%(\mathrm{~N}=14)$ & $13.9 \%(\mathrm{~N}=5)$ \\
\hline $51-60$ & $20.9 \%(\mathrm{~N}=34)$ & $19.4 \%(\mathrm{~N}=24)$ & $24.1 \%(\mathrm{~N}=21)$ & $26.0 \%(\mathrm{~N}=26)$ & $15.7 \%(\mathrm{~N}=11)$ & $32.0 \%(\mathrm{~N}=24)$ & $27.8 \%(\mathrm{~N}=10)$ \\
\hline Above 60 & $14.1 \%(\mathrm{~N}=23)$ & $16.9 \%(\mathrm{~N}=21)$ & $11.5 \%(\mathrm{~N}=10)$ & $12.0 \%(\mathrm{~N}=12)$ & $17.1 \%(\mathrm{~N}=12)$ & $17.3 \%(\mathrm{~N}=13)$ & $16.7 \%(\mathrm{~N}=6)$ \\
\hline \multicolumn{8}{|l|}{ Gender } \\
\hline Male & $51.5 \%(\mathrm{~N}=84)$ & $41.9 \%(\mathrm{~N}=52)$ & $43.7 \%(\mathrm{~N}=38)$ & $46.0 \%(\mathrm{~N}=46)$ & $44.3 \%(\mathrm{~N}=31)$ & $45.3 \%(N=34)$ & $58.3 \%(\mathrm{~N}=21)$ \\
\hline Female & $47.9 \%(\mathrm{~N}=78)$ & $56.5 \%(\mathrm{~N}=70)$ & $55.2 \%(\mathrm{~N}=48)$ & $53.0 \%(\mathrm{~N}=53)$ & $55.7 \%(\mathrm{~N}=39)$ & $53.3 \%(\mathrm{~N}=40)$ & $41.7 \%(\mathrm{~N}=15)$ \\
\hline \multicolumn{8}{|l|}{ Income } \\
\hline$\$ 0$ to 50,000 & $46 \%(N=75)$ & $37.1 \%(\mathrm{~N}=46)$ & $23.0 \%(\mathrm{~N}=20)$ & $33.0 \%(\mathrm{~N}=33)$ & $40.0 \%(\mathrm{~N}=28)$ & $20.0 \%(\mathrm{~N}=15)$ & $33.3 \%(\mathrm{~N}=12)$ \\
\hline $50,001-100,000$ & $34.4 \%(\mathrm{~N}=56)$ & $34.7 \%(\mathrm{~N}=43)$ & $36.8 \%(\mathrm{~N}=32)$ & $33.0 \%(\mathrm{~N}=33)$ & $35.7 \%(\mathrm{~N}=25)$ & $34.7 \%(\mathrm{~N}=26)$ & $30.6 \%(\mathrm{~N}=11)$ \\
\hline $100,001-150,000$ & $9.2 \%(\mathrm{~N}=15)$ & $9.7 \%(\mathrm{~N}=12)$ & $16.1 \%(\mathrm{~N}=14)$ & $13.0 \%(\mathrm{~N}=13)$ & $12.9 \%(\mathrm{~N}=9)$ & $21.3 \%(\mathrm{~N}=16)$ & $25.0 \%(\mathrm{~N}=9)$ \\
\hline$>$ than 150,000 & $9.8 \%(\mathrm{~N}=16)$ & $16.9 \%(\mathrm{~N}=21)$ & $24.1 \%(\mathrm{~N}=21)$ & $21.0 \%(\mathrm{~N}=21)$ & $11.4 \%(\mathrm{~N}=8)$ & $24.0 \%(\mathrm{~N}=18)$ & $11.1 \%(\mathrm{~N}=4)$ \\
\hline \multicolumn{8}{|l|}{ Education level } \\
\hline$<12$ th Grade & $4.3 \%(\mathrm{~N}=7)$ & $4.8 \%(\mathrm{~N}=6)$ & - & - & $7.1 \%(\mathrm{~N}=5)$ & - & $2.8 \%(\mathrm{~N}=1)$ \\
\hline $\begin{array}{l}\text { High school } \\
\text { diploma/GED }\end{array}$ & $4.9 \%(\mathrm{~N}=8)$ & $4.8 \%(\mathrm{~N}=6)$ & $1.1 \%(\mathrm{~N}=1)$ & $3.0 \%(\mathrm{~N}=3)$ & $5.7 \%(\mathrm{~N}=4)$ & - & $8.3 \%(\mathrm{~N}=3)$ \\
\hline Some college & $17.2 \%(\mathrm{~N}=28)$ & $18.5 \%(\mathrm{~N}=23)$ & $8.0 \%(\mathrm{~N}=7)$ & $8.0 \%(\mathrm{~N}=8)$ & $18.6 \%(\mathrm{~N}=13)$ & $9.3 \%(\mathrm{~N}=7)$ & $16.7 \%(\mathrm{~N}=6)$ \\
\hline $\begin{array}{l}\text { Associate degree/ } \\
\text { diploma }\end{array}$ & $10.4 \%(\mathrm{~N}=17)$ & $4.8 \%(\mathrm{~N}=6)$ & $4.6 \%(\mathrm{~N}=4)$ & $5.0 \%(\mathrm{~N}=5)$ & $7.1 \%(\mathrm{~N}=5)$ & $6.7 \%(\mathrm{~N}=5)$ & $8.3 \%(\mathrm{~N}=3)$ \\
\hline BA/BS & $27 \%(\mathrm{~N}=44)$ & $30.6 \%(\mathrm{~N}=38)$ & $34.5 \%(\mathrm{~N}=30)$ & $33.0 \%(\mathrm{~N}=33)$ & $30.0 \%(\mathrm{~N}=21)$ & $30.7 \%(\mathrm{~N}=23)$ & $33.3 \%(\mathrm{~N}=12)$ \\
\hline $\begin{array}{l}\text { MSc or higher } \\
\text { degree }\end{array}$ & $36.2 \%(\mathrm{~N}=59)$ & $34.7 \%(\mathrm{~N}=43)$ & $50.6 \%(\mathrm{~N}=44)$ & $50.0 \%(\mathrm{~N}=50)$ & $28.6 \%(\mathrm{~N}=20)$ & $52.0 \%(\mathrm{~N}=39)$ & $30.6 \%(\mathrm{~N}=11)$ \\
\hline \multicolumn{8}{|l|}{$\begin{array}{l}\text { Length of stay } \\
\text { in USA }\end{array}$} \\
\hline Less than a year & $9.8 \%(\mathrm{~N}=16)$ & $8.9 \%(\mathrm{~N}=11)$ & $2.3 \%(\mathrm{~N}=2)$ & $3.0 \%(\mathrm{~N}=3)$ & $14.3 \%(\mathrm{~N}=10)$ & - & $11.1 \%(\mathrm{~N}=4)$ \\
\hline $1-5$ years & $6.7 \%(\mathrm{~N}=11)$ & $4.0 \%(\mathrm{~N}=5)$ & $5.7 \%(\mathrm{~N}=5)$ & $7.0 \%(\mathrm{~N}=7)$ & $4.3 \%(\mathrm{~N}=3)$ & $1.3 \%(\mathrm{~N}=1)$ & $2.8 \%(\mathrm{~N}=1)$ \\
\hline $6-10$ years & $16.6 \%(\mathrm{~N}=27)$ & $14.5 \%(\mathrm{~N}=18)$ & $9.2 \%(\mathrm{~N}=8)$ & $10.0 \%(\mathrm{~N}=10)$ & $18.6 \%(\mathrm{~N}=13)$ & $10.7 \%(\mathrm{~N}=8)$ & $16.7 \%(\mathrm{~N}=6)$ \\
\hline $11-15$ years & $15.3 \%(\mathrm{~N}=25)$ & $13.7 \%(\mathrm{~N}=17)$ & $12.6 \%(\mathrm{~N}=11)$ & $12.0 \%(\mathrm{~N}=12)$ & $12.9 \%(\mathrm{~N}=9)$ & $8.0 \%(\mathrm{~N}=6)$ & $11.1 \%(\mathrm{~N}=4)$ \\
\hline$>15$ years & $50.9 \%(\mathrm{~N}=83)$ & $58.1 \%(\mathrm{~N}=72)$ & $69.0 \%(\mathrm{~N}=60)$ & $67.0 \%(\mathrm{~N}=67)$ & $48.6 \%(\mathrm{~N}=34)$ & $80.0 \%(\mathrm{~N}=60)$ & $58.2 \%(\mathrm{~N}=21)$ \\
\hline
\end{tabular}

*The percentages in some of the columns may not add up to 100, because a few respondents did not answer a specific question in the survey. 
Honey is found as an additive in many foods. It is a highly popular commodity which can be purchased by the jar or bottle. Honey can be taken orally to reduce irritation associated with allergic rhinitis, cough, and asthma. Ingestion can help with symptoms stemming from gastric ulcer associated with Helicobacter pylori. Topical use includes treatment of wounds, burns, sunburn, cataracts, diabetic foot ulcers, and post-herpetic corneal opacities. Topical use is safe as long as there is no previous history of allergy. Although evidence is lacking about the safe use of honey during pregnancy and breastfeeding, no serious adverse events have been reported other than possible allergic reaction (20).

\section{Citrus limon}

\section{Common name: Lemon; Vernacular name: Lomi}

A total of $87(42.2 \%)$ of our survey participants reported using lemon as a home remedy for various illnesses. Of these, 48 (55.2\%) were female. The majority of users $(52,59.8 \%)$ reported an annual income up to $\$ 100,000$, and $(44,50.6 \%)$ had a Master's degree or higher. The most common age range, and years lived in the USA were $41-50(23,26.4 \%)$ and $>15$ years $(60$, 69.0\%), respectively (Table 1 ).

Lemon is one of the most important fruit crops known by humans since ancient times, and a good source of vitamin $\mathrm{C}$ with high antioxidant potential. It is derived from trees that belong to the family Rutaceae $(21,22)$. Citrus is also among the most important fruit crops in Ethiopia, with an annual production of 77,087 tons (23). Ethiopia's agro-climatic conditions are highly suitable for production of high quality citrus fruits. Five phenological regions were identified based on the blooming season and climate as potential production centers capable of supplying citrus throughout the year. Lemon is found in open markets, grocery stores and small shops throughout Ethiopia and is one of the highest selling fruits in the country (24).

Lemon is ingested to treat scurvy (vitamin $\mathrm{C}$ deficiency), low resistance, colds, an antiinflammatory and diuretic. Oral consumption of lemon is safe in food-related doses and at higher doses for children and adults that are not pregnant. Historically, a normal food-level dose of lemon to prevent scurvy has been the equivalent of about $30 \mathrm{~mL}$ of the juice daily (21). Pregnant women should not take greater than food level doses (25).

\section{Eucalyptus globulus}

Common name: Blue gum; Vernacular name: Bahr zaf

Survey participants reported eucalyptus to be the seventh most commonly used natural remedy with a usage rate of $(70,34 \%)$. Over half $(39,55.7 \%)$ were female with $21(30.0 \%)$ reporting a BA/BS degree. $28(40 \%)$ had an annual income of less than $\$ 50,000$. The age group most frequently represented was $31-40(21,30.0 \%)$ and $34(48.6 \%)$ had resided in the USA for 15 years or more (Table 1).

Emperor Menelik had eucalyptus brought from Australia on the advent of the 20th century to alleviate the shortage of timber in Addis Ababa, the new Ethiopian capital city which was under construction at the time. Many plantations sprang up around the city and rapidly spread to other areas throughout the country as the tree is very resilient and readily adapts to a variety of environments (26).

The most common medicinal use of the plant in Ethiopia is for the management of cold symptoms (27). The leaves are steam distilled to extract eucalyptus oil. The oil has therapeutic, perfumery, flavoring, antimicrobial and bio-pesticidal properties. Eucalyptus is also used, although less often, internally and externally as an expectorant, and to treat infections and fever. It is also used topically to treat sore muscles and rheumatism (28). Eucalyptol is usually found in the form of oil, and is used in the production of cough lozenges, liniments, mouthwash, ointments and toothpaste (29).

Eucalyptus and eucalyptus oil are considered safe for use and consumption by both adults and older children, when used in normal amounts. The normal dose is 4 to $6 \mathrm{gm}$ of the leaves prepared as a tincture, or 0.3 to $0.6 \mathrm{gm}$ ( 0.05 to $0.2 \mathrm{~mL}$ ) of the oil daily (29). However, both the leaves and oil should be avoided in infants and young children because of potential toxicity, with reports of $3.5 \mathrm{~mL}$ or more of the concentrated oil leading to fatalities. Over exposure has also been associated with lethal toxicity. Data on safety during pregnancy or breastfeeding is lacking $(29,30)$.

\section{TABLE 1B}

Demographic characteristics of participants using herbs (B)

\begin{tabular}{|c|c|c|c|c|c|}
\hline Variables & $\begin{array}{l}\text { Damakese (Ocimum sp.) } \\
\qquad \mathrm{N}=35\end{array}$ & Moringa $\mathrm{N}=33$ & $\begin{array}{c}\text { Duba Fre (Cucurbita } \\
\text { pepo) } \mathrm{N}=30\end{array}$ & $\begin{array}{c}\text { Dingetegna (Taverniera } \\
\text { byssinica) } \mathrm{N}=15\end{array}$ & Tej Sar (Cymbogon citratus) $\mathrm{N}=8$ \\
\hline \multicolumn{6}{|l|}{ Age } \\
\hline $18-30$ & $14.3 \%(\mathrm{~N}=5)$ & $9.1 \%(\mathrm{~N}=3)$ & $3.3 \%(\mathrm{~N}=1)$ & $26.7 \%(\mathrm{~N}=4)$ & $12.5 \%(\mathrm{~N}=1)$ \\
\hline $31-40$ & $22.9 \%(\mathrm{~N}=8)$ & $15.2 \%(\mathrm{~N}=5)$ & $16.7 \%(\mathrm{~N}=5)$ & $20.0 \%(\mathrm{~N}=3)$ & $50.0 \%(\mathrm{~N}=4)$ \\
\hline $41-50$ & $25.7 \%(\mathrm{~N}=9)$ & $27.3 \%(\mathrm{~N}=9)$ & $33.3 \%(N=10)$ & - & $12.5 \%(\mathrm{~N}=1)$ \\
\hline $51-60$ & $11.4 \%(\mathrm{~N}=4)$ & $33.3 \%(\mathrm{~N}=11)$ & $20.0 \%(\mathrm{~N}=6)$ & $26.7 \%(\mathrm{~N}=4)$ & $12.5 \%(\mathrm{~N}=1)$ \\
\hline Above 60 & $25.7 \%(\mathrm{~N}=9)$ & $15.2 \%(\mathrm{~N}=5)$ & $23.3 \%(\mathrm{~N}=7)$ & $26.7 \%(\mathrm{~N}=4)$ & $12.5 \%(\mathrm{~N}=1)$ \\
\hline \multicolumn{6}{|l|}{ Gender } \\
\hline Male & $48.6 \%(\mathrm{~N}=17)$ & $60.6 \%(N=20)$ & $43.3 \%(\mathrm{~N}=13)$ & $46.7 \%(\mathrm{~N}=7)$ & $37.5 \%(\mathrm{~N}=3)$ \\
\hline Female & $51.4 \%(\mathrm{~N}=18)$ & $39.4 \%(\mathrm{~N}=13)$ & $56.7 \%(\mathrm{~N}=17)$ & $53.3 \%(\mathrm{~N}=8)$ & $62.5 \%(\mathrm{~N}=5)$ \\
\hline \multicolumn{6}{|l|}{ Income } \\
\hline$\$ 0$ to 50,000 & $65.7 \%(\mathrm{~N}=23)$ & $27.3 \%(\mathrm{~N}=9)$ & $50.0 \%(\mathrm{~N}=15)$ & $60.0 \%(\mathrm{~N}=9)$ & $50.0 \%(\mathrm{~N}=4)$ \\
\hline $50,001-100,000$ & $25.7 \%(\mathrm{~N}=9)$ & $36.4 \%(\mathrm{~N}=12)$ & $26.7 \%(\mathrm{~N}=8)$ & $13.3 \%(\mathrm{~N}=2)$ & $25.0 \%(\mathrm{~N}=2)$ \\
\hline $100,001-150,000$ & $8.6 \%(\mathrm{~N}=3)$ & $24.2 \%(\mathrm{~N}=8)$ & $16.7 \%(\mathrm{~N}=5)$ & $26.7 \%(\mathrm{~N}=4)$ & $25.0 \%(\mathrm{~N}=2)$ \\
\hline >than 150,000 & - & $12.1 \%(\mathrm{~N}=4)$ & $6.7 \%(\mathrm{~N}=2)$ & - & - \\
\hline \multicolumn{6}{|c|}{ Education level } \\
\hline$<12$ th Grade & $17.1 \%(\mathrm{~N}=6)$ & - & $13.3 \%(\mathrm{~N}=4)$ & $20.0 \%(\mathrm{~N}=3)$ & $12.5 \%(\mathrm{~N}=1)$ \\
\hline $\begin{array}{l}\text { High school diploma/ } \\
\text { GED }\end{array}$ & $8.6 \%(\mathrm{~N}=3)$ & - & $3.3 \%(\mathrm{~N}=1)$ & $6.7 \%(\mathrm{~N}=1)$ & $12.5 \%(\mathrm{~N}=1)$ \\
\hline Some college & $25.7 \%(\mathrm{~N}=9)$ & $12.1 \%(\mathrm{~N}=4)$ & $20.0 \%(\mathrm{~N}=6)$ & $13.3 \%(\mathrm{~N}=2)$ & $12.5 \%(\mathrm{~N}=1)$ \\
\hline $\begin{array}{l}\text { Associate degree/ } \\
\text { diploma }\end{array}$ & $8.6 \%(\mathrm{~N}=3)$ & $6.1 \%(\mathrm{~N}=2)$ & $6.7 \%(\mathrm{~N}=2)$ & $6.7 \%(\mathrm{~N}=1)$ & - \\
\hline $\mathrm{BA} / \mathrm{BS}$ & $34.3 \%(\mathrm{~N}=12)$ & $30.3 \%(N=10)$ & $30.0 \%(\mathrm{~N}=9)$ & $40.0 \%(\mathrm{~N}=6)$ & $50.0 \%(\mathrm{~N}=4)$ \\
\hline MSc or higher degree & $5.7 \%(\mathrm{~N}=2)$ & $51.5 \%(\mathrm{~N}=17)$ & $26.7 \%(\mathrm{~N}=8)$ & $13.3 \%(\mathrm{~N}=2)$ & $12.5 \%(\mathrm{~N}=1)$ \\
\hline \multicolumn{6}{|c|}{ Length of stay in USA } \\
\hline Less than a year & $22.9 \%(\mathrm{~N}=8)$ & $3.0 \%(\mathrm{~N}=1)$ & $16.7 \%(\mathrm{~N}=5)$ & $20.0 \%(\mathrm{~N}=3)$ & $12.5 \%(\mathrm{~N}=1)$ \\
\hline $1-5$ years & $11.4 \%(\mathrm{~N}=4)$ & $3.0 \%(\mathrm{~N}=1)$ & $6.7 \%(\mathrm{~N}=2)$ & - & $12.5 \%(\mathrm{~N}=1)$ \\
\hline $6-10$ years & $22.9 \%(\mathrm{~N}=8)$ & $6.1 \%(\mathrm{~N}=2)$ & $13.3 \%(\mathrm{~N}=4)$ & $20.0 \%(\mathrm{~N}=3)$ & $25.0 \%(\mathrm{~N}=2)$ \\
\hline $11-15$ years & $11.4 \%(\mathrm{~N}=4)$ & $12.1 \%(\mathrm{~N}=4)$ & $6.7 \%(\mathrm{~N}=2)$ & $13.3 \%(\mathrm{~N}=2)$ & $12.5 \%(\mathrm{~N}=1)$ \\
\hline$>15$ years & $31.4 \%(\mathrm{~N}=11)$ & $75.8 \%(\mathrm{~N}=25)$ & $53.3 \%(\mathrm{~N}=16)$ & $46.7 \%(\mathrm{~N}=7)$ & $37.5 \%(\mathrm{~N}=3)$ \\
\hline
\end{tabular}




\section{Boswellia spp.}

Common name: Incense; Vernacular name: i'tan

\section{Commiphora spp.}

\section{Common name: Myrrh; Vernacular name: Kerbe}

Less than one-in-five $(36,17.5 \%)$ of survey respondents used i'tan and kerbe. Over half $(21,58.3 \%)$ were male, 12 (33\%) had attained a bachelor's degree, and $21(58.2 \%)$ had residence in the USA for more than 15 years. Most frequently represented age group and income level were 51-60 (10, 27.8\%) and less than $\$ 50,000(12,33.3 \%)$ respectively (Table 1$)$.

Boswellia and Commiphora species is a combination of two natural remedies, both belonging to the family Burseraceae. This combination is commonly referred to as frankincense and myrrh. These resin extracts have been used in African countries for many years. While the local use of this commodity is mostly ceremonial, there is growing demand for folk medicine and home fumigation purposes. Gum, especially incense, still remains a major export commodity in Ethiopia with 3,500 tons (worth around 11.8 million dollars) being sold in 2011/12 (31). Western industrial countries use this product in the manufacturing of confectionery, food and beverages, cosmetics and pharmaceutical products (32).

Oral ingestion of the resin treats a wide variety of ailments including upper respiratory illness, arthritis and bursitis pain, cancer, leprosy, and syphilis. The resin can also be applied topically to treat aphthous ulcers, gingivitis, hemorrhoids, furunculosis, and bad breath. Both species are safe for ingestion and topical application in adults and children. Large oral doses may lead to diarrhea and kidney irritation, and excess topical use may cause dermatitis. This product is best avoided by pregnant women as potential abortifacient effects have been reported. There is a paucity of data for safety in breastfeeding mothers (32).

\section{Ocimum spp.}

\section{Common name: Basil; Vernacular name: Damakese}

Ocimum utilization among survey respondents was about $17 \%$. There was no significant gender difference and two-thirds had an annual income of less than $\$ 50,000$. Level of education was reported as BA/BS degree by 12 $(34.3 \%)$ of respondents and $11(31.4 \%)$ resided in the USA for greater than 15 years. Most users were in the age group 41-50 (9, 25.7\%) and greater than $60(9,25.7 \%)$ (Table 1).

In Ethiopian traditional medicine, damakese (family Lamiacea/Labiatae) is mostly used for the treatment of a disease condition commonly known as "mitch", which is characterized by headache, fever, inflammation, joint pain, back pain, chills, sweat, loss of appetite, and in severe cases, diarrhea. "Mitch" is believed to be caused by exposure to strong sunlight immediately after baking, roasting of cereals, heating of red pepper and spices, and in general after engaging in tasks that expose one to strong smell, or smoke. Another manifestation of "mitch" which is referred to as "girifat" may include formation of blisters, mostly on the border of the lips, inflammation of the outer and/or inner parts of the lips and gum, tearing of the tongue, and whitening and inflammation of the mouth (33).

Damakese is used as leaf juice with coffee or tea. It is common practice to apply the leaves topically and massage the face and/or body. It is also employed for the treatment of common cold and cough alone or with eucalyptus. Other indications of the plant include eye infection, for which the decoction of the crushed leaves is applied, and hematuria where the patient drinks the decoction. The broad-spectrum bactericidal and fungicidal potentials of the oil as well as its freeradical scavenging activity support its traditionally claimed medicinal values (33). Damakese is a specialty shop and internet ordered item in the United States, and it is not widely used among the population as a whole.

\section{Moringa spp.}

\section{Common name: Moringa; Vernacular name: Aleko, Shiferaw}

The popularity of moringa as a medicinal herb in Ethiopia has significantly increased over the last 5-10 years. This ascendance is not appropriately reflected in our study as three-fourth of the respondents have resided in the USA for over a decade. Although only $15.5 \%$ (33) reported using the plant, we would anticipate a much higher user rate if we focused on a more recent immigrant population. The demographic data for moringa users was age range of $51-60$ years $=11(33.3 \%)$, male $=20(60.6 \%)$, annual income between $\$ 50,001-100,000=12(36.4 \%)$ and $17(51.5 \%)$ with a Master's or higher degree (Table 1).

Among the six Moringa species found in Ethiopia, it appears that M. stenopetala is the most widely used. It is known locally as shiferaw or aleko (34). In southern Ethiopia, the leaf of the plant is used as a substitute for cabbage in the local diet and as animal feed. It has been demonstrated that it is rich in carbohydrates, proteins, fats, minerals and fiber (35). Studies have also shown that the plant is a reasonably good natural purifier of muddy and contaminated water. Local communities use it for diabetes, hypertension, asthma, trypanosomiasis, malaria and unspecified stomach problems. Preliminary studies, especially those that were conducted in Ethiopia, appear to support its traditional use $(34,36)$.

A review of studies on leaf extracts of in normal doses revealed no adverse effects. However, toxicity studies on the seed and root extracts were inconclusive. In general, based on human, animal and in vitro studies, it appears that various extracts of $\mathrm{M}$. oleifera are safe when used at nutritional and normal doses equivalent to 4.6 to $8 \mathrm{gm}$ of the leaf powder daily (37).

\section{Cucurbita pepo}

\section{Common name: Pumpkin; Vernacular name: Duba Fre}

$14.6 \%$ (30) of our survey respondents used pumpkin seeds during the specified study period. Females were a slight majority $(17,56.7 \%)$ and 15 $(50 \%)$ reported an annual income of less than $\$ 50,000$. The most frequently represented age group was $41-50(10,33.3 \%)$ and $9(30.0 \%)$ had attained a $\mathrm{BA} / \mathrm{BS}$ degree, while 16 (53.3\%) had resided in the US for 15 years or longer (Table 1).

There are several herbal remedies used to treat taeniasis, such as Echinops gigantea (dendero), Embelia schimperi (enkoko), Glinus lotoides (metere) and Thymus serrulatus (tossign). Pumpkin seeds (duba) are also fairly effective with a favorable safety profile (38). Information regarding the safety of pumpkin in pregnancy and lactation are lacking (39).

Other ailments treated with pumpkin include bladder irritation, prostate complaints, kidney inflammation and to promote wound healing (40). Pumpkin seeds are often roasted and consumed as a snack. They can be found anywhere in the United States during the autumn season, but are typically harder to find the rest of the year. However, extracts are sold at vitamin/nutrition stores and select pharmacies.

\section{Taverniera abyssinica}

\section{Vernacular name: Dingetegna}

Dingetegna was one of the least commonly used natural remedies among our survey participants. $15(7.3 \%)$ reported using it at any time during the past 5 years with almost even distribution among the age groups. $8(53.3 \%)$ were female and $6(40 \%)$ had attained a BA/BS degree. Annual income of $\$ 0$ to 50,000 was reported by $9(60 \%)$ participants and $7(46.7 \%)$ and had resided in the USA for over 15 years (Table 1).

Dingetegna is an Amharic word for "medicine for sudden illness". The plant belongs to the family Leguminosae. The root is commonly used for its antipyretic, antacid and analgesic properties. Some research findings have confirmed the basis for the traditional use of this plant in treating stomach pain and fever, which were generally referred to as sudden illness symptoms $(41,42)$. It is not surprising that the plant is losing its popularity among Ethiopian immigrants in the USA as there are effective and readily available OTC medications for fever and mild stomach ailments. Moreover, there are no conclusive human studies to determine appropriate dosage and/or whether dingetegna is safe to use during pregnancy or breastfeeding. Dingetegna is not found among the commonly available products in the USA. Products containing dingetegna are available at specialty Ethiopian stores and websites.

\section{Cymbopogon citratus}

\section{Common name: Lemon grass; Vernacular name: Tej sar}

Lemon grass (Tej sar) was the least commonly used natural remedy among our survey respondents $(8.4 \%)$ (Table 1$)$. It is a perennial aromatic tropical grass that belongs to the family Poaceae $(43,44)$. Lemon grass is one of the 140 species that comprise the genus Cymbopogon. It is an aromatic grass that yields a wide array of essential oils useful in perfumery (43). The name lemon grass is derived from the typical lemon-like odor present in the shoot. 
Lemon grass has been used traditionally for cough, cold, rheumatism, lumbago, digestive and bladder problems, leprosy, and as a mouthwash for toothache and swollen gums. It has also been used as a stimulant and diuretic (44). In Ethiopia, the leaf is used as a perfume, and in folk medicine for the treatment of heart, chest and stomach complaints (45).

Lemon grass oil has low toxicity when used in low doses. Since information is lacking regarding safety in pregnant and breast-feeding women, its use is not recommended in these conditions (46). Lemon grass oil can be found at most grocery stores, department stores, and pharmacies in the USA. It is also an ingredient in many fragrances and deodorants.

\section{CONCLUSION}

This review was culled from a previous survey conducted by the same authors and attempts to take a more in-depth look at the use of specific natural remedies by Ethiopian immigrants in the USA. It is safe to conclude that herbs and supplements traditionally used in Ethiopia have found their way to the USA and are just as commonly utilized for medicinal purposes. It is also reasonable to infer that the use of natural remedies by this population is a conscious choice and a reflection of deeply imbedded traditional/ cultural values, and not necessarily a path of last resort due to lack of access to conventional medicine. While there is increasing evidence that natural remedies have a legitimate place in the armamentarium of pharmaceuticals, each herb and supplement described is this paper must be separately researched prior to use, as treatment regimens have to take into account the unique attributes of an individual patient.

\section{REFERENCES}

1. WHO. (2016, November 2). WHO Medicines Strategy - Countries at the Core - 2004 - 2007: Components of the strategy: Component 2. National policies on traditional medicine and complementary and alternative medicine. Retrieved from Essential Medicines and Health Products Information Portal: obtained from: http://apps.who.int/medicinedocs/ $\mathrm{en} / \mathrm{d} / \mathrm{Js} 5416 \mathrm{e} / 5.2 . \mathrm{html}$.

2. Hailemeskel B, Habte A, Fullas F, et al. A survey on the use of complementary and alternative medicine among Ethiopian Immigrants in the USA. J Complementary Med Alt Healthcare 2017; 1:555568

3. Fullas F. Spice plants in Ethiopia: Their culinary and medicinal applications. Sioux City, Iowa; 2013:159.

4. Geta E, Kifle A. Production, processing and marketing of ginger in Southern Ethiopia. Journal of Horticulture and Forestry. 2011; 3:207-213.

5. Jellin JM, Gregory P, Batz F, et al. Pharmacists Letter/Prescriber's Letter Natural Medicines Comprehensive Database. 3rd ed. Stockton, CA: Therapeutic Research Faculty, 2000: 475-477.

6. Der Marderosian A, Beutler JA. Ginger. The review of natural products. St. Louis, MO: Wolter Kluwer Health, Inc., Nov 1991.

7. Bayan L, Koulivand PH, Gorij A. Garlic: A review of potential therapeutic effects. Avicenna J Phytomed 2014;4:1-14.

8. Jellin, Op cit, pp 464-468.

9. Fleming T, ed. PDR for Herbal remedies. 1st ed. Montvale, NJ: Medical Economics Co, 1998: 626-628.

10. Dilbato DD, Tito TM. Medicinal preparation and use of garlic by traditional healers in Southern Nations Nationalities and Peoples State, Ethiopia. Ethiop J Health Dev 1999; 13: 93-99.

11. Der Marderosian A, Beutler JA. Garlic. The review of natural products. St. Louis, MO: Wolter Kluwer Health, Inc., Sept 2008.

12. Jacobsz MJ, Van der Merwe. WJC: Production guidelines for flax (Linum usitatissimum L.). Department of Agriculture, Forestry and Fisheries Directorate: Plant production, South Africa 2012.

13. Goyal A, Sharma V, Upadhyay N, et al. Flax and flaxseed oil: An ancient medicine \& modern functional food. J Food Sci Technol 2014; 51: 1633-1653.

14. Negash W, Asfaw Z, Yibrah H. Linseed (Linum usitatissimum L.) ethnobotany and cultivation status in Ethiopia. Int J Agric Appl Sci 2012; 4:48-57.

15. Geleta M, Asfaw Z, Bekele E, et al. Edible oil crops and their integration with major cereals in Northern Shewa and South Wello, Centra
Highland of Ethiopia: an ethnobotanical perspective. Hereditas 2002;137:29-40.

16. Der Marderosian A, Beutler JA. Flax. The review of natural products. St. Louis, MO: Wolter Kluwer Health, Inc., July 2004.

17. Market \& Agribusiness Development. Obtained from: http://ethioagp. org/honey-2/.

18. Honey: Ethiopia's Liquid Gold. African Business Magazine 20 JULY 2012. Obtained from: http://africanbusinessmagazine.com/ uncategorised/honey-ethiopias-liquid-gold/.

19. Drugs and Supplements. Honey. http://www.mayoclinic.org/ drugssupplements/honey/background/hrb-20059618.

20. Natural Medicines Comprehensive Data Base. Prescriber's Letter/ Pharmacist's Letter http://naturaldatabase.therapeuticresearch.com/ nd/Search. $\cdot$ aspx $? \mathrm{cs}=\& \mathrm{~s}=\mathrm{ND} \& \mathrm{pt}=100 \& \mathrm{id}=738 \& \mathrm{ds}=\&$ name $=$ HONEY\& searchid $=62292459 \#$ top.

21. Der Marderosian A, Beutler JA. Lemon. The review of natural products. St. Louis, MO: Wolter Kluwer Health, Inc., July 2004

22. Gorinstein S, Martin BO, Park Y, et al. Comparison of some biochemical characteristics of different citrus fruits. Food Chemistry 2001;74:309-315.

23. Dagnew A, Belew D, Admassu B, et al. Citrus production, constraints and management practices in Ethiopia: The case of Pseudocercospora leaf and fruit spot disease. Sci Technol Arts Res J 2014; 3 (2): 4-18.

24. Mekonen M, Ayalew A, Woldetsadik K, et al. Assessing and measuring Citrus gummosis (Phytophthora spp.) in major citrus growing areas of Ethiopia. J Horticulture 2015; 2:4

25. Jellin JM, Gregory P, Batz F, et al. Pharmacists Letter/Prescriber's Letter Natural Medicines Comprehensive Database. 3rd ed. Stockton, CA Therapeutic Research Faculty, 2000: 659-670.

26. Mystery and Wonder. The Journey Revealed. Eucalyptus in Ethiopia https://pcwoolner.wordpress.com/2013/10/20/eucalyptus-in-ethiopia/.

27. Fullas F. Ethiopian Traditional Medicine: Common Medicinal Plants in Perspective. Sioux City, Iowa, USA, 2001:91-92.

28. Armando CC, Rahma HU. Evaluation of the yield and the antimicrobia activity of the essential oils from: Eucalyptus globulus, Cymbopogon citratus and Rosmarinus officinalis in Mbarara District (Uganda). Rev Colombiana Cienc Anim 2009; 1: 240-249.

29. Jellin JM, Gregory P, Batz F, et al. Pharmacists Letter/Prescriber's Letter Natural Medicines Comprehensive Database. 3rd ed. Stockton, CA Therapeutic Research Faculty, 2000: 407-409.

30. Fleming T, et al. PDR for Herbal remedies. 1st ed. Montvale, NJ: Medical Economics Company, 1998: 836-839.

31. Araya E. Smoky Perfume. Addis Fortune. Obtained from: https:// addisfortune.net/articles/smokey-perfume/.

32. Jellin JM, Gregory P, Batz F, et al. Pharmacists Letter/Prescriber's Letter Natural Medicines Comprehensive Database. 3rd ed. Stockton, CA: Therapeutic Research Faculty, 2000,449-450 \& 747-748.

33. Kifle H. Seyoum A, Asres K, et al. Composition, antimicrobial, and free radical scavenging properties of the essential oil of Damakese (Ocimumm lamifolium): A popular remedy in Ethiopia. Int J Essential Oil Ther 2007;1:110-116.

34. Addis G, Jiru D, Mekonnen Y, et al. Moringa [Moringa stenopetala Bak.f. (Cufod)]. Guide to Use and Processing Practices. Horn of Africa Regional Environment Center and Network, Addis Ababa University, Ethiopia, 2014:3-11.

35. Seifu E. Actual and potential applications of Moringa stenopetala underutilized indigenous vegetable od southern Ethiopia: A Review. Int J Agric \& Food Res 2014;3:8-19.

36. Tadele A, Debela A. Proceeding of Consultative Workshop on Moringa stenopetala to maximize its potential use. Bishoftu, Ethiopia. The Ethiopian Public Health Institute;2014.

37. Stohs SJ, Hartman MJ. Review of safety of Moringa oleifera. Phytother Res 2015;29:796-804. 
38. Desta B. Ethiopian herbal drugs. Part I. Studies on the toxicity and therapeutic activity of traditional taenicidal medications. J Ethnopharmacol 1995;45:27-33.

39. Der Marderosian A, Beutler JA. Pumpkin. The review of natural products. St. Louis, MO: Wolter Kluwer Health, Inc., July 2004.

40. Fleming T, et al. PDR for herbal remedies. 1st ed. Montvale, NJ: Medical Economics Company, 1998: 784-785.

41. Dagne E, Abate D, Stadler M, et al. Biologically active compounds from diverse sources. In: Fourth NAPRECA Symposium on Natural Products. Addis Ababa, Ethiopia: Ethiopia, 1991 pp. 14-18.

42. Noames BK, Bogale M, Dagne E. Intestinal smooth muscle spasmolytic actions of the aqueous extract of the roots of Taverrniera abyssinica. J Ethnopharmacol 1990;30:107-113.

43. Kumari J, Verma V, Goyal A, et al. Genetic diversity analysis in Cymbopogon species using DNA markers. Plant Omics Journal 2009;2: 20-29.

44. Hassan VU, Saleem M, Shaffi N, et al. Lemongrass: Botany, ethnobotany and chemistry. Pak J Weed Sci Res 2007;13: 129-134.

45. Asfaw N, Demissew S. Aromatic plants of Ethiopia. Addis Ababa, Ethiopia: Shama Books, 2009:157

46. Jellin JM, Gregory P, Batz F, et al. Pharmacists Letter/Prescriber's Letter Natural Medicines Comprehensive Database. 3rd ed. Stockton, CA: Therapeutic Research Faculty, 2000: 652-653. 